\title{
Metallic Pb nanospheres in ultra-high temperature metamorphosed zircon from southern India
}

\author{
M. J. Whitehouse ${ }^{1}$ - M. A. Kusiak ${ }^{2,3}$ - R. Wirth ${ }^{3}$ - G. R. Ravindra Kumar ${ }^{4}$
}

Received: 24 March 2017 / Accepted: 12 June 2017 /Published online: 1 July 2017

(C) The Author(s) 2017. This article is an open access publication

\begin{abstract}
A transmission electron microscope (TEM) study of Paleoproterozoic zircon that has experienced ultra-high temperature (UHT) metamorphism at ca. $570 \mathrm{Ma}$ in the Kerala Khondalite Belt (KKB), southern India, documents the occurrence of metallic $\mathrm{Pb}$ nanospheres. These results permit comparison with a previous report from UHT zircon in Enderby Land, Antarctica, and allow further constraints to be placed on possible mechanisms for nanosphere formation. As in Enderby Land, the nanospheres in the KKB occur in non-metamict zircon, emphasising that radiogenic $\mathrm{Pb}$ redistribution can occur with only partial interconnectivity of radiation damaged zircon. In contrast, the nanospheres reported here are not closely associated with Si-rich glass inclusions, which is inconsistent with a silicate liquid-metal immiscibility model proposed in the earlier study. Formation of these $\mathrm{Pb}$ nanospheres effectively halts $\mathrm{Pb}$-loss from zircon, even under extreme conditions, and can adversely affect geochronological interpretations due to decoupling of $\mathrm{Pb}$ from $U$.
\end{abstract}

Editorial handling: L. Nasdala

M. J. Whitehouse

Martin.Whitehouse@nrm.se

1 Department of Geosciences, Swedish Museum of Natural History, Box 50007, SE-104 05 Stockholm, Sweden

2 Institute of Geological Sciences, Polish Academy of Sciences, PL00818 Warsaw, Poland

3 GeoForschungsZentrum, Section 4.3 Chemistry and Physics of Earth Materials, D-14473 Potsdam, Germany

4 National Centre for Earth Science Studies, Akkulam, Thiruvananthapuram 695011, India
Keywords Zircon · Ultra-high temperature metamorphism • Transmission electron microscope $\cdot$ Lead isotopes $\cdot$ Kerala Khondalite Belt

\section{Introduction}

Zircon $\left(\mathrm{ZrSiO}_{4}\right)$ is arguably the most widely used and reliable geochronometer currently available. During crystallization, highly incompatible $\mathrm{Pb}$ is excluded from the zircon crystal structure, while $\mathrm{U}$ and $\mathrm{Th}$ are readily incorporated and their radioactive decay leads over time to an accumulation of purely radiogenic $\mathrm{Pb}$ that facilitates radiometric dating. While zircon is generally highly resistant to post-crystallization disturbance, even during medium- to high-grade metamorphism, radiogenic $\mathrm{Pb}$ hosted in regions damaged by $\alpha$-recoil can become mobile and may be partially or completely lost from the crystal. Consequently, partial or complete resetting of the U-Th- $\mathrm{Pb}$ geochronometer can occur. Although the processes of $\mathrm{Pb}$-loss and resetting are reasonably well-understood, with data obtained from such disturbed zircon often still amenable to simple interpretation, zircon that has experienced ultra-high temperature (UHT) metamorphism has sometimes been reported to exhibit localised "Pb gain", notably when analysed at high spatial and volume resolution using, for example, secondary ion mass spectrometer (SIMS) methodology (Williams et al. 1984; Kelly and Harley 2005; Kusiak et al. 2013a, b; Whitehouse et al. 2014). Manifested, during the course of an analysis, as unstable $\mathrm{Pb}$ emission relative to stable $\mathrm{U}$, $\mathrm{Th}$, and matrix peak emission, recent studies using high spatial resolution (ca. $2 \mu \mathrm{m}$ ) scanning ion imaging have revealed $\mathrm{Pb}$-rich clots in UHT-affected zircon from Enderby Land in Eastern Antarctica (Kusiak et al. 2013a, b), and in the Kerala Khondalite Belt (KKB, also referred to as the Trivandrum Block) in Southern India (Whitehouse et al. 2014). These 
$\mathrm{Pb}$-rich clots occur on a scale at least as small as the $2 \mu \mathrm{m}$ primary ion beam utilised in these studies. In both cases, the development of these clots readily explains disturbed $\mathrm{U}-\mathrm{Pb}$ geochronology, specifically: (i) excess analytical uncertainty in the ${ }^{207} \mathrm{~Pb} /{ }^{206} \mathrm{~Pb}$ ratio relative to that expected from counting statistics, (ii) ${ }^{207} \mathrm{~Pb} /{ }^{206} \mathrm{~Pb}$ ages that are older than the likely protolith age of the host rock, and (iii) common reverse discordance of analyses of such zircon due to the presence of unsupported radiogenic $\mathrm{Pb}$. Applying a scanning ion tomography methodology, which combines scanning ion imaging with depth profiling, to the zircon grains from two KKB samples, the size of the $\mathrm{Pb}$ clots was estimated to be a few tens of $\mathrm{nm}$, much smaller than the lateral resolution of the method (Whitehouse et al. 2014).

The nanometer scale of the $\mathrm{Pb}$-rich regions was confirmed by a transmission electron microscope (TEM) study of the zircon grains from Enderby Land, which further revealed that $\mathrm{Pb}$ is present as ca. 5-35 nm diameter metallic nanospheres (Kusiak et al. 2015). In these zircon grains, the $\mathrm{Pb}$ nanospheres occur either as individual droplets or are associated with an amorphous silica-rich phase and an unidentified Ti-Al amorphous phase. Electron diffraction patterns of the host zircon revealed various degrees of radiation damage in its crystalline structure. No correlation between $\mathrm{Pb}$ distribution and degree of crystallinity nor significant plastic deformation was observed in the analysed grains (Kusiak et al. 2017). Kusiak et al. (2015) proposed that during metamorphism of radiation damaged zircon, nanoscale islands of crystallinity act as nucleation sites for lattice recrystallisation, trapping radiogenic $\mathrm{Pb}$ in amorphous zircon domains. As the temperature increases, melting of these amorphous domains results in the localised concentration of $\mathrm{Pb}$, with subsequent cooling accompanied by metal $(\mathrm{Pb})$ - silicate immiscibility. Important consequences of this model are that (i) metamictisation is not a prerequisite for $\mathrm{Pb}$ nanosphere development and (ii), once formed, the combination of newly-crystallised zircon and a stable $\mathrm{Pb}$ phase effectively arrests the process of $\mathrm{Pb}$-loss, potentially explaining the paradox of why zircon that has experienced the extreme conditions of UHT metamorphism has not been completely reset to its metamorphic age.

In the present study, TEM is used to investigate zircon grains from the KKB that exhibit Pb-rich clots. These results facilitate a comparison of zircon behaviour in two UHT terranes of different protolith ages, timing and temperature of metamorphism.

\section{Geological setting, samples and previous study}

The geological setting of the two KKB samples, which host the zircon grains investigated in this study, has been described in detail by Whitehouse et al. (2014) and is only briefly summarised here. The KKB is a Paleoproterozoic mobile belt in southern India that was extensively reworked in latest Neoproterozoic to early-Cambrian time, during the Pan African orogeny (Sreejith and Ravindra Kumar 2013; Whitehouse et al. 2014; Ravindra Kumar and Sreejith 2016; Harley and Nandakumar 2016). Divided into a number of crustal blocks separated by major shears zones (Braun and Kriegsman 2003), the samples studied here come from the central Ponmudi Unit, which is comprised locally of migmatised garnet-biotite and garnet-sillimanite gneisses, as well as high-K granites, the latter interpreted to have formed during arc accretion (Sreejith and Ravindra Kumar 2013). Ravindra Kumar and Sreejith (2016) recently proposed a four-stage crustal evolution model for the KKB, with juvenile magmatism on an over-thickened oceanic-arc followed by multiple episodes of intra-crustal melting causing crustal differentiation. A prominent feature of the KKB is the development of what are termed "incipient charnockites", which consist of localised, often outcrop-scale, orthopyroxene-bearing granitic paragneiss patches (Ravindra Kumar et al. 1985), thought to result from influx of $\mathrm{CO}_{2}$-rich fluids (Newton and Tsunogae 2014).

Estimates vary on the peak temperature attained during metamorphism in the KKB, but most studies suggest that the entire block reached at least $900^{\circ} \mathrm{C}$, the nominal UHT boundary (Harley 1998). Similarly, the precise timing of this metamorphism is unclear, most methods returning ages in the range 580-510 Ma, although the most recent estimates for the UHT event are towards the older end of this range (Whitehouse et al. 2014; Blereau et al. 2016). Incipient charnockite formation is generally considered as a relatively low temperature $\left(<650^{\circ} \mathrm{C}\right)$ process (e.g. Harlov et al. 2006). At some KKB localities, it appears to have occurred at close to peak UHT conditions and prior to melting (Blereau et al. 2016), while elsewhere, including at the locality studied here, charnockite patches clearly cross-cut anatectic features in the host gneisses (Whitehouse et al. 2014), consistent with a later overprint. Episodic Pb-loss in zircon rims has been used to propose a separate metamorphism, possibly related to the charnockitisation event, ca. 40-50 Ma after peak UHT conditions were attained (Whitehouse et al. 2014). Regardless of the precise timing of events at specific localities, it is likely that Pan African metamorphism of the KKB was polyphase, consistent with the field observations.

The two zircon grains investigated here by TEM belong to samples derived from a locally charnockitised, high-K metagranite exposed in a quarry at Elavattom $\left(8^{\circ} 40.606^{\prime} \mathrm{N}\right.$, $\left.77^{\circ} 01.620^{\prime} \mathrm{E}\right)$, ca. $25 \mathrm{~km}$ northeast of the city of Thiruvananthapuram, Kerala. Sample IN8-6 represents the dominant metagranite and adjacent sample IN8-4 represents the locally developed, tens of centimetre scale (arrested or incipient) charnockite. Their morphology, rare 
earth element (REE), and U-Th-Pb characteristics have been extensively described by Whitehouse et al. (2014). In both samples, cathodoluminescence (CL) imaging reveals polyphase zircon, with fine oscillatory-zoned cores, which have typically igneous REE profiles, overgrown by relatively homogeneous rims of variable thickness from a few to a few tens of micrometers. Secondary ion mass spectrometer (SIMS) U-Th- $\mathrm{Pb}$ analyses of the cores show an absence of non-radiogenic (common) $\mathrm{Pb}$, with ${ }^{206} \mathrm{~Pb} /{ }^{204} \mathrm{~Pb}$ ratios in four of the five analysed spots shown in Fig. 1 in excess of 100,000 , corresponding to $<0.02 \%$ common $\mathrm{Pb}$ (the fifth analysis still $<0.2 \%$; see Table $\mathrm{S} 1$ of Whitehouse et al. 2014). These analyses indicate a protolith age of ca. $1850 \mathrm{Ma}$, but the precision of this age is limited both by normal and reverse discordance and unusually large errors in ${ }^{207} \mathrm{~Pb} /{ }^{206} \mathrm{~Pb}$ ratios that are well in excess of counting statistics. The zircon rims in both samples are consistently depleted in middle- to heavy-REE, indicating that their initial crystallization was in equilibrium with garnet during a high-grade metamorphic event at ca. $570 \mathrm{Ma}$. The spread in age to ca. $510 \mathrm{Ma}$ was attributed to Pb-loss during a separate charnockitisation event towards the younger age of this range (Whitehouse et al. 2014). Scanning ion imaging of the zircon cores (Fig. 1) revealed the presence of Pb-rich clots, which, together with ion tomographic evidence for their tens of nanometer size (Whitehouse et al. 2014), readily explains the unstable emission of $\mathrm{Pb}$ during the $\mathrm{U}-\mathrm{Th}-\mathrm{Pb}$ analyses and reverse discordance of some of the analyses.

\section{Methodology}

Two foils of zircon were prepared for TEM study applying the site-specific focused-ion-beam (FIB) technique that allows cutting of an electron-transparent foil from pre-selected areas of interest (Lee et al. 2003; Wirth 2009). The TEM foils are ca. 15-20 $\mu \mathrm{m} \times 10-15 \mu \mathrm{m}$ in size and a $100 \mathrm{~nm}$ thick. A glass fibre attached to a micro-manipulator was used to lift out foils from the excavation sites. Details of the technique are given in Wirth (2004).

Analytical and energy-filtered high-resolution transmission electron microscope (ATEM, HRTEM) investigation utilised a FEI TecnaiTM G2 F20 X-Twin operating at $200 \mathrm{kV}$ with a field emission gun (FEG) electron source. The TEM is equipped with a post-column Gatan imaging filter (GIF Tridiem). The HRTEM images presented are energy-filtered using a $10 \mathrm{eV}$ window on the zero loss peak. The TEM analysis was performed with an EDAX $\mathrm{X}$-ray analyser equipped with an ultra-thin window. The $\mathrm{X}$-ray intensities were measured in scanning transmission mode (STEM) where the electron beam is serially scanned

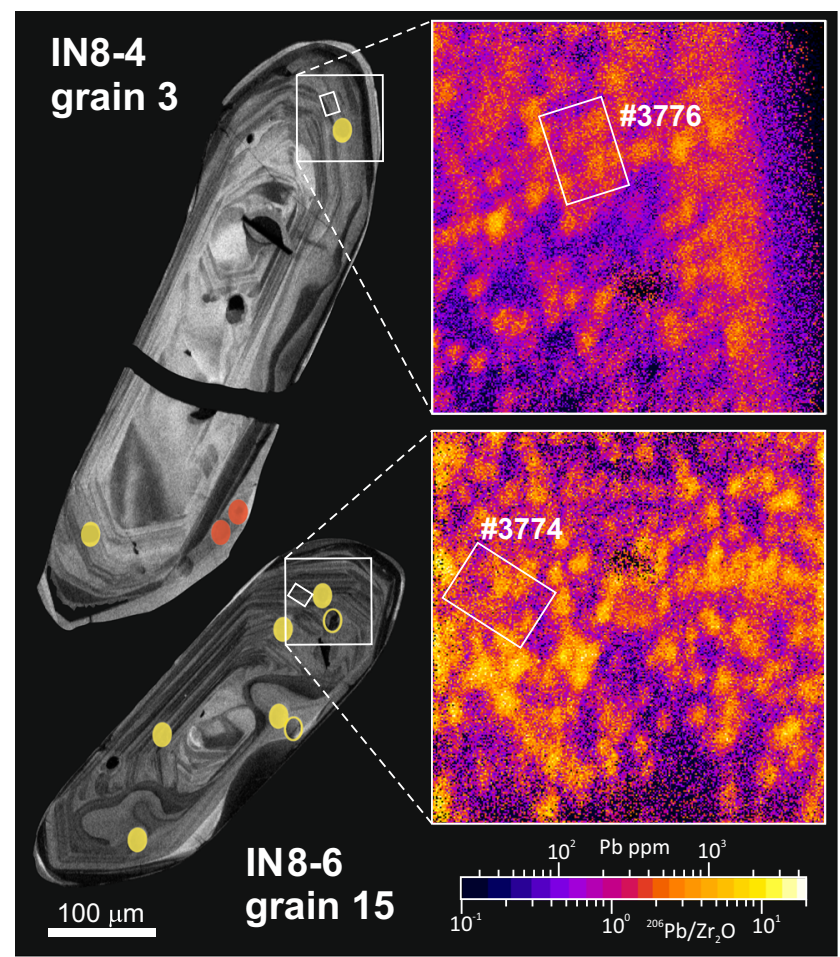

Fig. 1 CL images of zircon from IN8-4 (charnockite) and IN8-6 (high$\mathrm{K}$ metagranite) samples together with scanning ion images of the distribution of $\mathrm{Pb}$ (modified after Whitehouse et al., 2014). Coloured ellipses on the CL images show the location of U-Pb (filled) and REE (open) spot analyses; yellow and red ellipses indicate areas yielding ca. $1.85 \mathrm{Ga}$ "core" ages and ca. $570 \mathrm{Ma}$ "rim" ages respectively (Whitehouse et al., 2014); the rim in IN8-6 grain 15 was too thin to target. Scanning ion image is scaled as ${ }^{206} \mathrm{~Pb}^{+}$normalised to matrix proxy species $\mathrm{Zr}_{2} \mathrm{O}^{+}$, with nominal concentration calibrated relative to an image of the standard zircon. Large white squares on the CL images show the area investigated by scanning ion imaging $(80 \times 80 \mu \mathrm{m})$. White rectangles in the $\mathrm{CL}$ and scanning ion images show the location where the FIB foils were cut

over a pre-selected area, minimizing mass loss during data acquisition.

\section{Results}

Transmission electron microscope investigation of foils taken from two oscillatory zoned core areas of the zircon grains previously investigated by scanning ion imaging (see Fig. 1 for location) reveals that these grains contain numerous nanoscale spherical inclusions, visible as bright and dark spots in the high-angle annular dark-field (HAADF) images from each foil (Fig. 2a, e). Energy-dispersive X-ray (EDX) analysis of areas that include the bright inclusions yield prominent $\mathrm{Pb}$ peaks (Fig. 3a, d), which are absent in analysis of inclusionfree parts of the zircon (Fig. 3b, e). Although most of the bright spots, which range in size from 2 to $15 \mathrm{~nm}$, are too small to permit detailed analysis, in several cases diffraction patterns could be obtained by Fast Fourier Transform (FFT) from high-resolution lattice fringe images. The observed 


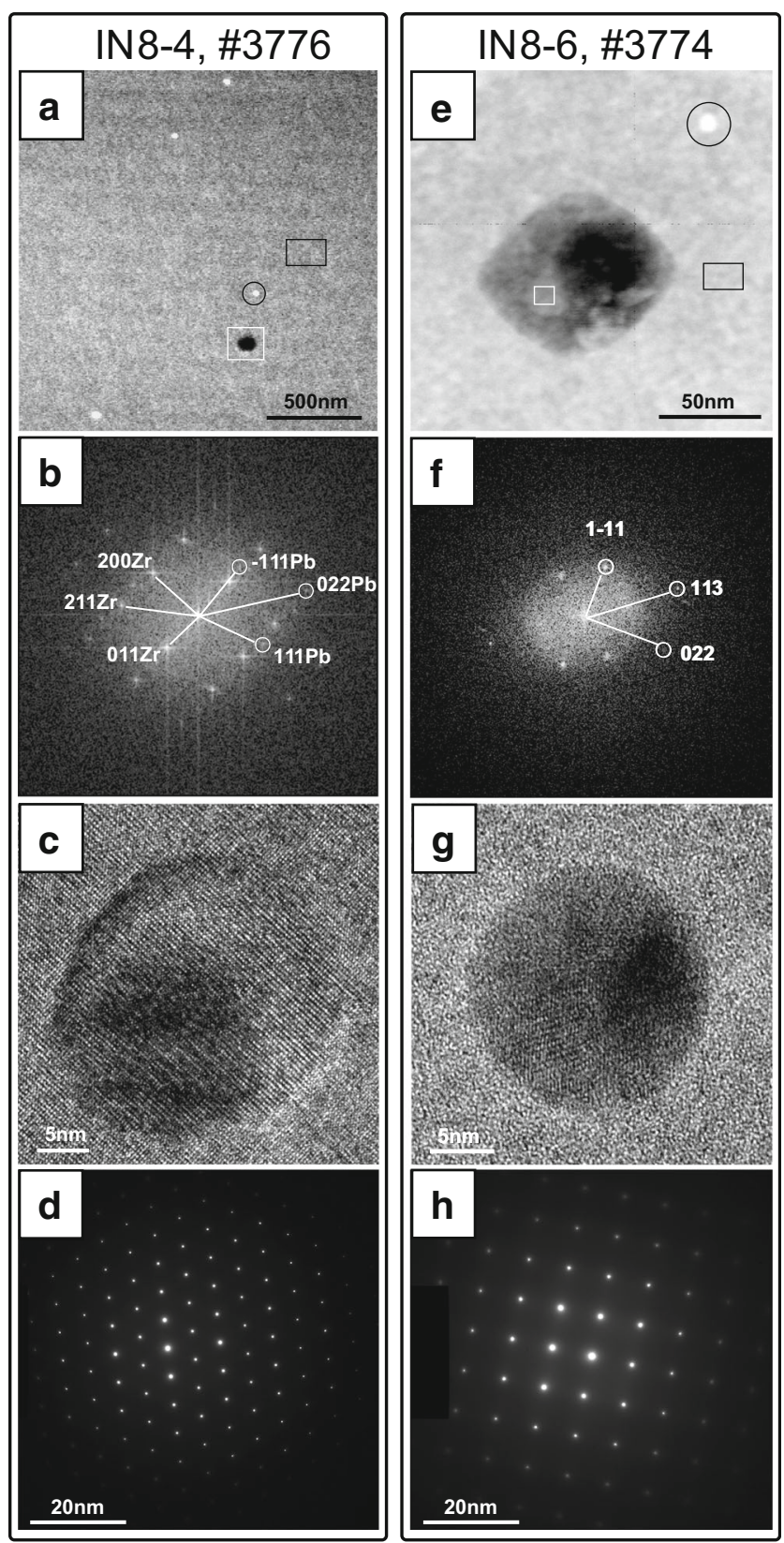

Fig. 2 TEM results from a-d charnockite sample IN8-4, e-h high-K metagranite sample IN8-6. a, e High-angle annular dark-field (HAADF) TEM images showing $\mathrm{Pb}$ nanospheres in the zircon. Areas of the EDX spectra presented in Fig. 3 are highlighted. Black circles indicate analysed $\mathrm{Pb}$ nanospheres. White squares indicate analysed Sirich glass. Black squares indicate analysed zircon. b, f FFT of the HRTEM images of the $\mathrm{Pb}$ nanospheres shown in a and $\mathbf{e}$ (marked with a black circle). In $\mathbf{f}$ the diffraction pattern (FFT) is indexed according to native $\mathrm{Pb}$ with a cubic structure; in $\mathbf{b}$ diffraction spots from zircon and $\mathrm{Pb}$ visible on the image are indexed. $\mathbf{c}, \mathbf{g}$ HRTEM images of the $\mathrm{Pb}$ nanospheres shown in a and e. $\mathbf{d}, \mathbf{h}$ Diffraction patterns of zircon shown in a and e. The diffraction patterns do not show any indication of metamictization

angles between the diffraction planes (1-11) and (113) and between (113) and (022) are, respectively, $57^{\circ}$ and $32^{\circ}$ (e.g. Fig. 2f). These angles, together with agreement between the observed ( $n=17)$ and calculated d spacing, lead us to conclude that the diffraction pattern can only be indexed as cubic $\mathrm{Pb}$ (Table 1). Due to a lack of detectable sulphur, cubic $\mathrm{PbS}$ can be excluded from the list of potential $\mathrm{Pb}$ species, and no $\mathrm{Pb}$ oxide or silicate phases are cubic, hence, these nanospheres must be composed of native $\mathrm{Pb}$. High-resolution TEM (HRTEM) images of these $\mathrm{Pb}$ nanospheres (Fig. 2c, g) show that the surrounding zircon lattice is devoid of damage or metamictization. This observation is further confirmed by sharp zircon diffraction patterns (Fig. 2d, h), which lack the smeared-out and/or scattered reflections and rings that are characteristic of radiation damaged zircon (cf. Fig. 3 in Kusiak et al. 2015).

Energy-dispersive X-ray analysis of areas, that include the dark spots, shows that these have a higher $\mathrm{Si} / \mathrm{Zr}$ ratio (Fig. 3c, f) than the inclusion free-zircon (Fig. 3b, e) and are therefore likely to represent a Si-rich phase. In one case (Fig. 2e) the inclusion appears to be more complex, with a less dark outer region that contains a trace amount of Fe (Fig. 3f).

As a general observation, Si-rich phases are larger than the metallic $\mathrm{Pb}$ nanospheres in both samples, but they are less common. Based on the available dataset all of the nanospheres are heterogeneously distributed and occur singly, never as composite inclusions.

\section{Discussion}

The detection of randomly distributed metallic $\mathrm{Pb}$ nanospheres in zircon from these two KKB samples shows that this phenomenon is not unique to Enderby Land, from where it was originally reported (Kusiak et al. 2015), and that their presence may be a more common phenomenon in UHT terranes. In both cases, Si-rich glass inclusions are also found, containing trace levels of $\mathrm{Al}$ and $\mathrm{Ti}$ in the Enderby Land example and trace levels of $\mathrm{Fe}$ in the KKB. At the time of UHT metamorphism, the accumulated $\alpha$ doses of $1.5 \times 10^{18}$ and $2.5 \times 10^{18} \alpha / \mathrm{g}$ based on the spot U-Pb analyses of the two grains (Table S1 in Whitehouse et al. 2014) are similar to two of the three grains investigated from Enderby Land. This observation strengthens the conclusion of Kusiak et al. (2015) that metamictization of zircon is not a prerequisite for $\mathrm{Pb}$ nanosphere formation. These doses bracket the value of $2.4 \times 10^{18} \alpha / \mathrm{g}$ (Pidgeon 2014, revised after Murakami et al. 1991 and Salje et al. 1999), which defines the so-called "first percolation point" where amorphous domains in zircon begin to form an interconnected network. These values should not, however, be considered as precise because the concentration determined by SIMS is subject to several tens of percent uncertainty based on heterogeneity in the reference zircon. Furthermore, fine-scale oscillatory zoning, visible in CL on a scale smaller than the ca. $20 \mu \mathrm{m}$ analysed spot from which the concentration was determined, reflects variations in the $\mathrm{U}$ 
Fig. 3 EDX results from areas highlighted in Fig. 2. a-c

Charnockite sample IN8-4 and df high-K metagranite sample IN8-6. All spectra include a contribution from the zircon matrix and, where relevant, that of the inclusion. Additionally, $\mathrm{Cu}$ peaks from the grid and $\mathrm{Ga}$ implanted during FIB foil preparation are present in all spectra. a, $\mathbf{d}$ Spectra showing $\mathrm{Pb}$ peaks from $\mathrm{Pb}$ nanospheres. b, e Spectra of inclusionfree zircon. c, $\mathbf{f}$ Spectra of silicarich inclusions. Note the much higher $\mathrm{Si} / \mathrm{Zr}$ ratios compared to spectra from inclusion-free zircon $\mathbf{b}, \mathbf{e}$ indicating their Si-enriched nature

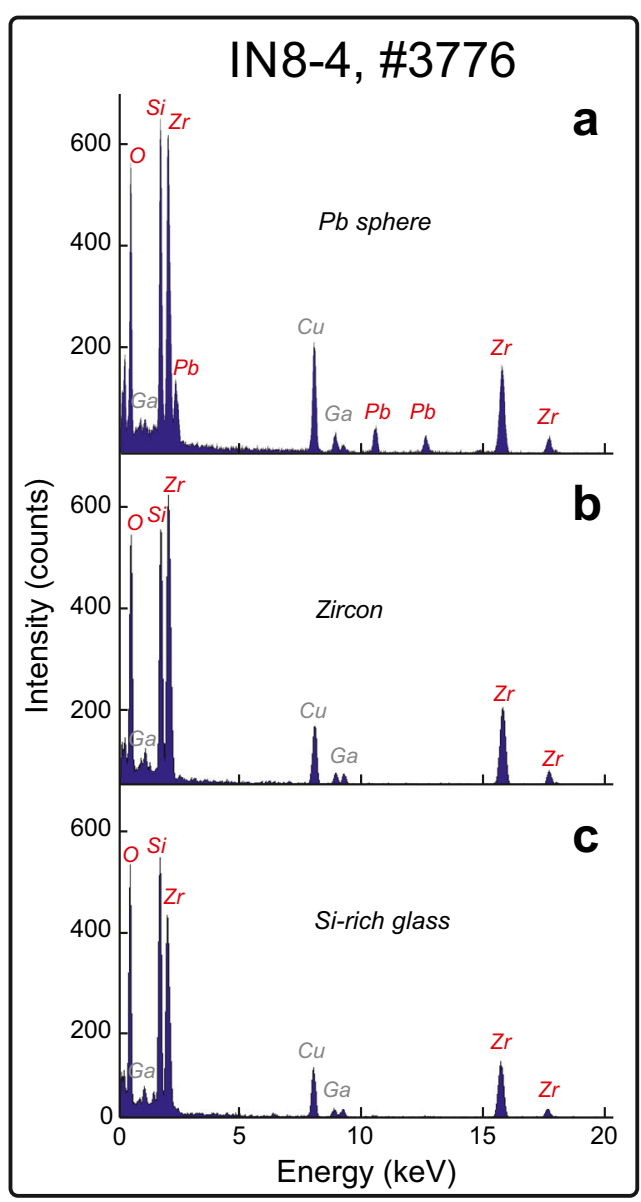

Table 1 Unit-cell constants and d spacings of the $\mathrm{Pb}$ nanospheres analysed here, compared with published values for native $\mathrm{Pb}$ and $\mathrm{Pb}$ oxides

\begin{tabular}{|c|c|c|c|c|c|c|}
\hline $\mathrm{Pb}$ phase & $\begin{array}{l}\mathrm{Pb} \\
\text { nanospheres * }\end{array}$ & $\mathrm{Pb}$ & $\mathrm{PbO}$ & $\mathrm{PbO}_{2}$ & $\mathrm{~Pb}_{2} \mathrm{O}_{3}$ & $\mathrm{~Pb}_{3} \mathrm{O}_{4}$ \\
\hline Crystal system & Cubic & Cubic & Orthorhombic & Orthorhombic & Monoclinic & Tetragonal \\
\hline \multirow{4}{*}{$\begin{array}{l}\text { Unit-cell } \\
\text { constants }\end{array}$} & $\mathrm{a}_{0}=4.92 \AA * *$ & $\mathrm{~b}_{0}=5.4930 \AA$ & $\mathrm{a}_{0}=5.8952 \AA$ & $\mathrm{a}_{0}=4.9858 \AA$ & $\mathrm{a}_{0}=7.8140 \AA$ & $\mathrm{a}_{0}=8.8118 \AA$ \\
\hline & & & $\mathrm{b}_{0}=5.9590 \AA$ & $\mathrm{b}_{0}=5.6250 \AA$ & $\mathrm{b}_{0}=8.8118 \AA$ & $\mathrm{a}_{0}=8.8118 \AA$ \\
\hline & & & $c_{0}=4.7544 \AA$ & $\mathrm{c}_{0}=5.4626 \AA$ & $\mathrm{c}_{0}=8.4650 \AA$ & $\mathrm{c}_{0}=6.5639 \AA$ \\
\hline & & & & & $\beta=124.97^{\circ}$ & \\
\hline \multirow[t]{7}{*}{$\begin{array}{c}\mathrm{d}_{\mathrm{hkl}} \text { observed } \\
{[\AA]}\end{array}$} & $\begin{array}{l}4.76-4.84 \\
(100)\end{array}$ & $\begin{array}{l}4.9505 \\
\quad(001)(010)(100) * * *\end{array}$ & $4.7544(001)$ & $4.9858(100)$ & $4.4294(-102)$ & 4. $5185(111)$ \\
\hline & $\begin{array}{l}2.84-2.85 \\
\quad(111)\end{array}$ & $2.858(111)$ & & & $2.8125(020)$ & \\
\hline & & & $2.7465(020)$ & $2.7310(002)$ & & $2.7863(310)$ \\
\hline & & & $2.4896(120)$ & $2.4929(200)$ & & $2.5216(212)$ \\
\hline & & $2.475(020)$ & $2.3782(021)$ & $2.3952(102)$ & $2.4894(21-3)$ & $2.4437(230)$ \\
\hline & $1.72(022)$ & $1.750(022)$ & $1.7974(022)$ & $1.7591(212)$ & 1.7665 (113) & 1.7907 (412) \\
\hline & $1.45(113)$ & $1.565(113)$ & $1.5146(302)$ & $1.5290(132)$ & $\begin{array}{l}1.4570(-2-1-3) \\
1.4563(0-3-3)\end{array}$ & $1.5111(350)$ \\
\hline References & (this study) & Lide (1983-1984) & $\begin{array}{l}\text { Garnier et al. } \\
\text { (1990) }\end{array}$ & $\begin{array}{l}\text { Filatov et al. } \\
\text { (2005) }\end{array}$ & $\begin{array}{l}\text { Bouvaist and Weigel } \\
\text { (1970) }\end{array}$ & $\begin{array}{l}\text { Gavarri and Weigel } \\
\text { (1975) }\end{array}$ \\
\hline
\end{tabular}

*The d spacings quoted are based on measurement of 17 individual nanospheres

**Calculated from d spacing

****Forbidden reflection 
content, a CL quenching element (Hanchar and Rudnick 1995). On this scale of zoning, it seems likely that darker $\mathrm{CL}$, more U-rich zones may overstep the first percolation point boundary while CL-lighter, more U- depleted zones remain below it.

Despite these similarities, there are also significant differences between both occurrences, which may provide further clues to the process of metallic nanosphere formation under UHT conditions. The $\mathrm{Pb}$ nanospheres are generally smaller and of lower abundance in the KKB zircons and in all observed cases, occur independently of the Si-rich glass inclusions, while in the Enderby Land example, most of the $\mathrm{Pb}$ nanospheres occur themselves as inclusions in the Si-rich glass. Additionally, in the $\mathrm{KKB}$ example, the zircon surrounding the nanospheres is highly crystalline, whereas in the Enderby Land example the nanospheres occur only in regions of lower crystallinity (Kusiak et al. 2015).

The observation of lower crystallinity zircon in the vicinity of the Si-rich and $\mathrm{Pb}$ nanospheres led Kusiak et al. (2015) to postulate a model (see their Figure 4) involving initial accumulation of radiogenic $\mathrm{Pb}$ in structurally damaged regions of the zircon crystal. Under UHT conditions, these regions then melted to yield immiscible Si-rich and $\mathrm{Pb}$ phases, which separated on cooling by liquid-metal immiscibility. Annealing and recovery of the zircon structure resulted in a mosaic of crystalline "islands" (Nasdala et al. 2004) with slightly different lattice orientations. Such a mosaic texture will be manifested by elliptical distortion of the diffraction spots (as described in detail by Anderson et al. 2008). However, the diffraction patterns from both KKB zircon grains (Fig. $2 \mathrm{~d}$ and h) show very sharp diffraction spots with no signs of rings with diffuse intensity. The model developed by Kusiak et al. (2015) was based on the observation of mosaic textures in the analysed grains that had sufficiently high $\mathrm{U}+$ Th content to have become metamict at the time of metamorphism (of which one grain was presented as an example in Kusiak et al. 2015). The other two grains examined by Kusiak et al. (2015) were, like the KKB examples described here, close to the first percolation point where there would have been some, but not full, connectivity of radiation damaged domains. The development of $\mathrm{Pb}$ nanospheres in such a relatively little-damaged zircon therefore suggests that the process might be controlled by smaller-scale, localised variations of radiation damage; for example in the more $\mathrm{U}(+\mathrm{Th})$ rich zones. Furthermore, the apparent decoupling of the $\mathrm{Pb}$ nanospheres and Si-rich melt, together with the observation of fully crystalline zircon in the KKB example, precludes a direct analogue with the process described by Kusiak et al. (2015).

Subtle differences exist between Enderby Land and the $\mathrm{KKB}$ in both the nature of the UHT metamorphism and the prevailing state of the zircon. In Enderby Land, the UHT event reached $1100{ }^{\circ} \mathrm{C}$, whereas in the $\mathrm{KKB}$, the peak temperature likely just exceeded the UHT boundary of ca. $900{ }^{\circ} \mathrm{C}$. Additionally, in the KKB, the UHT event was followed by incipient charnockitisation, possibly during a separate event ca. 40-50 Ma after peak UHT conditions were attained (Whitehouse et al. 2014). Regardless of the precise post-UHT $\mathrm{P}-\mathrm{T}$ evolution, specifically whether temperatures remained relatively high, reheating occurred, or both, a prolonged period with temperatures above $\sim 500{ }^{\circ} \mathrm{C}$ would have resulted in more complete annealing of the zircon, which might in part explain the higher level of crystallinity observed in the KKB zircon compared to Enderby Land. It should be stressed, however, that the charnockitisation is a secondary process overprinting the rocks after UHT conditions and it likely played no role in the primary formation of the $\mathrm{Pb}$ nanospheres.

Investigations of the location of $\mathrm{Pb}$ in zircon on the atomic scale using atom probe tomography (APT) have been reported by several groups (Valley et al. 2014, 2015; Peterman et al. 2016; Piazolo et al. 2016). All of these studies documented clustering of $\mathrm{Pb}$ atoms in zircon but not the formation of metallic $\mathrm{Pb}$ spheres similar to those observed in UHT zircon by TEM (this study; Kusiak et al. 2015, 2017). While various mechanisms for $\mathrm{Pb}$ mobilization have been proposed in these APT studies, all require an increase of temperature to trigger $\mathrm{Pb}$ movement, though not necessarily to UHT conditions. While these studies are of considerable interest in understanding the mechanism of radiogenic $\mathrm{Pb}$ mobility in zircon, and likely represent typical behaviour under less extreme metamorphic conditions, we reiterate the observation made by Kusiak et al. (2015) that the concentration of $\mathrm{Pb}$ in the nanoscale clusters revealed by APT are typically comprised of a few thousands of atoms compared to in excess of 100,000 atoms in a $20 \mathrm{~nm}$ metallic $\mathrm{Pb}$ nanosphere. Taken together with their observed homogeneity, the APTrevealed $\mathrm{Pb}$ clusters will not affect the high spatial/volume resolution, U-Pb geochronology analysis undertaken by e.g. SIMS in the same way as seen for the metallic $\mathrm{Pb}$ nanospheres.

\section{Conclusions}

A TEM study of Palaeoproterozoic zircon from the Kerala Khondalite Belt, southern India that experienced UHT metamorphism at ca. $570 \mathrm{Ma}$, has revealed a second occurrence of metallic $\mathrm{Pb}$ nanospheres alongside that reported previously from Enderby Land, Antarctica. Since UHT metamorphism is common to both regions and, given the fact that such nanospheres have only been reported so far in zircons from areas that have experienced this extreme metamorphic grade, the mechanism to generate them appears to be related to these conditions. There are subtle differences in the mode of occurrence of the nanospheres between the two examples, those in the KKB zircons occurring separately from Si-rich melt and surrounded by fully crystalline zircon. While the latter can potentially be explained by later reheating in the $\mathrm{KKB}$, which occurred during localised charnockitization shortly after the UHT event, the separate occurrence of metallic $\mathrm{Pb}$ nanospheres and Si-rich melt rules out 
operation of a liquid immiscibility mechanism that has been proposed for Enderby land. Regardless of how these $\mathrm{Pb}$ nanospheres formed, their presence clearly prevents the loss of radiogenic $\mathrm{Pb}$ from the zircon crystal and, hence, complete resetting to the age of UHT metamorphism.

Acknowledgements The authors wish to thank Daniel Harlov and two anonymous reviewers for their insightful reviews, together with Lutz Nasdala for careful editorial handling. This work was partly supported by grants from the Swedish Research Council to MJW. MAK acknowledges a Humboldt Fellowship at the GFZ and Anja Schreiber for technical help. GRR thanks the Director, National Centre for Earth Science Studies, Thiruvananthapuram for support.

Open Access This article is distributed under the terms of the Creative Commons Attribution 4.0 International License (http:// creativecommons.org/licenses/by/4.0/), which permits unrestricted use, distribution, and reproduction in any medium, provided you give appropriate credit to the original author(s) and the source, provide a link to the Creative Commons license, and indicate if changes were made.

\section{References}

Anderson AJ, Wirth R, Thomas R (2008) The alteration of metamict zircon and its role in the remobilization of high-field-strength elements in the Georgeville granite, Nova Scotia. Can Mineral 46:1-18

Blereau E, Clark C, Taylor RJM, Johnson TE, Fitzsimons ICW, Santosh M (2016) Constraints on the timing and conditions of high-grade metamorphism, charnockite formation and fluid-rock interaction in the Trivandrum Block, southern India. J Metamorph Geol 34:527549

Bouvaist J, Weigel D (1970) Sesquioxide de plomb, $\mathrm{Pb}_{2} \mathrm{O}_{3}$. I. Determination de la structure. Acta Crystallogr A 26:501-510

Braun I, Kriegsman LM (2003) Proterozoic crustal evolution of southernmost India and Sri Lanka. In: Yoshida M, Windley BF, Dasgupta S (eds) Proterozoic East Gondwana: Supercontinent assembly and breakup, vol 206. Geol Soc London Spec Publ, pp169-202

Filatov S, Bendeliani N, Albert B, Kopf J, Dyuzeva T, Lityagina L (2005) High-pressure synthesis of $\alpha-\mathrm{PbO}_{2}$ and its crystal structure at 293, 203, and $113 \mathrm{~K}$ from single crystal diffraction data. Solid State Sci 7: $1363-1368$

Garnier P, Moreau J, Gavarri JR (1990) Analyse de rietveld de la structure de $\mathrm{Pb} 1-\mathrm{xTixO} 1+\mathrm{x}$ par diffraction des neutrons. Mater Res Bull 25: 979-986

Gavarri JR, Weigel D (1975) Oxydes de plomb. I. Structure crystalline du minimum $\mathrm{Pb}_{3} \mathrm{O}_{4}$, à température ambiante $(293 \mathrm{~K})$. J Solid State Chem 11:344-345

Hanchar JM, Rudnick RL (1995) Revealing hidden structures: The application of cathodoluminescence and back-scattered electron imaging to dating zircons from lower crustal xenoliths. Lithos 36:289303

Harley SL (1998) On the occurrence and characterization of ultrahightemperature crustal metamorphism. In: Treloar PJ, O’Brien PJ (eds) What drives metamorphism and metamorphic reactions?, vol 138. Geol Soc Lond Spec Publ, pp 81-107

Harley SL, Nandakumar V (2016) New evidence for Palaeoproterozoic high grade metamorphism in the Trivandrum Block, Southern India. Precambrian Res 280:120-138

Harlov DE, Johansson L, Van den Kerkhof A, Förster H-J (2006) The role of advective fluid flow and diffusion during localized, solid-state dehydration: Söndrum Stenhuggeriet, Halmstad, SW Sweden. JPetrol 47:3-33
Kelly NM, Harley SL (2005) An integrated microtextural and chemical approach to zircon geochronology: Refining the Archaean history of the Napier Complex, east Antarctica. Contrib Mineral Petr 149:5784

Kusiak MA, Dunkley DJ, Wirth R, Whitehouse MJ, Wilde S, Marquardt $\mathrm{K}$ (2015) Metallic lead nanospheres discovered in ancient zircons. $\mathrm{P}$ Natl Acad Sci USA 112(16):4958-4963

Kusiak MA, Whitehouse MJ, Wilde S, Dunkley DJ, Menneken M, Nemchin AA, Clark C (2013a) Changes in zircon chemistry during Archean UHT metamorphism in the Napier Complex, Antarctica. Am J Sci 313(9):933-967

Kusiak MA, Whitehouse MJ, Wilde SA, Nemchin AA, Clark C (2013b) Mobilization of radiogenic $\mathrm{Pb}$ in zircon revealed by ion imaging: Implications for early Earth geochronology. Geology 41(3):291294

Kusiak MA, Wilde S, Wirth R, Whitehouse MJ, Dunkley DJ, Lyon, I, Reddy SM (2017) Detecting micro- and nano-scale variations in element mobility in high- grade metamorphic rocks: implication for precise U-Pb dating of zircon. Microstructural Geochronology; Lattice to Atom-Scale Records of Planetary Evolution (in-press)

Lee MR, Bland PA, Graham G (2003) Preparation of TEM samples by focused ion beam (FIB) techniques: applications to the study of clays and phyllosilicates in meteorites. Mineral Mag 67(3):581-592

Lide DR (1983-1984) Handbook of Chemistry and Physics. CRS Press, Boca Raton, FL

Murakami T, Chakoumakos BC, Ewing RC, Lumpkin GR, Weber WJ (1991) Alpha-decay event damage in zricon. Am Mineral 76:1510 1532

Nasdala L, Reiners PW, Garver JI, Kennedy AK, Stern RA, Balan E, Wirth R (2004) Incomplete retention of radiation damage in zircon from Sri Lanka. Am Mineral 89:219-231

Newton RC, Tsunogae T (2014) Incipient charnockite: Characterization at the type localities. Precamb Res 253:38-49

Peterman EM, Reddy SM, Saxey DW, Snoeyenbos DR, Rickard WDA, Fougerouse D, Kylander-Clark ARC (2016) Nanogeochronology of discordant zircon measured by atom probe microscopy of $\mathrm{Pb}$ enriched dislocation loops. Sci Adv 2:e1601318

Piazolo S, La Fontaine A, Trimby P, Harley S, Yang L, Armstrong R, Cariney JM (2016) Deformation-induced trace element redistribution in zircon revealed using atom probe tomography. Nat Commun 7:20490

Pidgeon RT (2014) Zircon radiation damage ages. Chem Geol 367:13-22

Ravindra Kumar GR, Sreejith C (2016) Petrology and geochemistry of charnockites (felsic ortho-granulites) from the Kerala Khondalite Belt, Southern India: Evidence for intra-crustal melting, magmatic differentiation and episodic crustal growth. Lithos $262: 334-354$

Ravindra Kumar GR, Srikantappa C, Hansen E (1985) Charnockite formation at Ponmudi, southern India. Nature 313:207-209

Salje EKH, Chrosch J, Ewing RC (1999) Is "metamictization" of zircon a phase transition? Am Mineral 84:1107-1116

Sreejith C, Ravindra Kumar GR (2013) Petrogenesis of high-K metagranites in the Kerala Khondalite Belt, southern India: a possible magmatic-arc link between India, Sri Lanka, and Madagascar. J Geodyn 63:69-82

Valley JW, Cavosie AJ, Ushikubo T, Reinhard DA, Lawrence DF, Larson DJ, Clifton PH, Kelly TF, Wilde SA, Moser DE, Spicuzza (2014) Hadean age for a post- magma-ocean zircon confirmed by atomprobe tomography. Nat Geosci 7(3):219-223

Valley JW, Reinhard DA, Cavosie AJ, Ushikubo T, Lawrence DF, Larson DJ, Kelly TF, Snoeyenbos DR, Strockland A (2015) Nano- and micro-geochronology in Hadean and Archean zircons by atomprobe tomography and SIMS: new tools for old minerals. Am Mineral 100:1355-1377

Whitehouse MJ, Kumar GRR, Rimša A (2014) Behaviour of radiogenic $\mathrm{Pb}$ in zircon during ultrahigh-temperature metamorphism: an ion 
imaging and ion tomography case study from the Kerala Khondalite Belt, southern India. Contrib Mineral Petr 168(2):1-18

Williams IS, Compston W, Black LP, Ireland TR, Forster JJ (1984)

Unsupported radiogenic $\mathrm{Pb}$ in zircon: a case of anomalously high $\mathrm{Pb}-\mathrm{Pb}, \mathrm{U}-\mathrm{Pb}$ and $\mathrm{Th}-\mathrm{Pb}$ ages. Contrib Mineral Petr 88:322-327
Wirth R (2004) Focused Ion Beam (FIB): a novel technology for advanced application of micro- and nanoanalysis in geosciences and applied mineralogy. Eur J Mineral 16:863-876

Wirth R (2009) Focused Ion Beam (FIB) combined with SEM and TEM: advanced analytical tools for studies of chemical composition, microstructure and crystal structure in geomaterials on a nanometre scale. Chem Geol 261:217-229 